\title{
Pengaruh Stimulasi Motorik Halus Terhadap Tahap Perkembangan Psikososial Anak Usia Pra Sekolah
}

\author{
Livana PH ${ }^{1 *}$, Dhita Armitasari ${ }^{2}$, Yulia Susanti ${ }^{3}$ \\ 1,2,3 Program Studi Ilmu Keperawatan, Sekolah Tinggi Ilmu Kesehatan, Kendal, Indonesia \\ *Email korespondensi: livana.ph@gmail.com
}

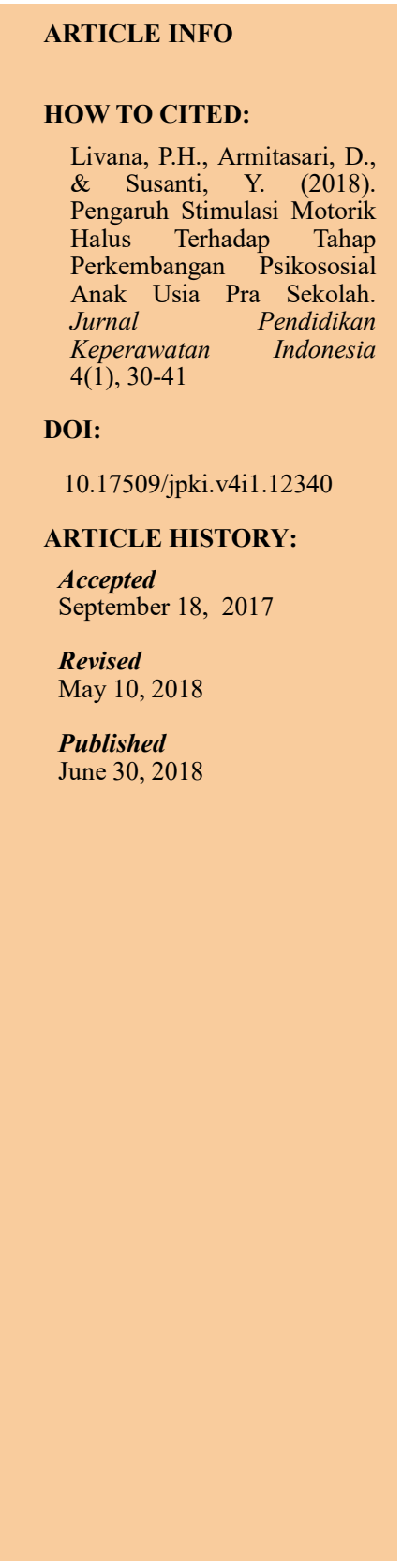

\begin{abstract}
A B S T R A K
Masa usia prasekolah merupakan masa emas, dimana perkembangan seorang anak akan banyak mengalami perubahan yang sangat berarti. Anak usia prasekolah memiliki potensi yang besar untuk berkembang, potensi tersebut berkembang dengan melakukan kegiatan motorik halus yang dilatih atau digunakan. Besar kecilnya naluri bergerak bagi anak tidak selalu sama. Agar pertumbuhan anak usia prasekolah dapat optimal maka diberikan stimulasi untuk memberikan rangsangan terhadap seluruh aspek perkembangan anak. Tahap perkembangan motorik halus anak akan mampu dicapai secara optimal asal mendapatkan stimulasi tepat. Tujuan penelitian untuk mengetahui pengaruh stimulasi motorik halus terhadap tahap perkembangan psikososial anak usia pra sekolah (3-6 tahun) di TK Kecamatan Kota Kendal. Desain penelitian yang digunakan adalah kuasi eksperimen with control group pre post test design. Sampel anak usia prasekolah yang ada di TK Kecamatan Kota Kendal yaitu TK Muslimat sebanyak 33 responden dan TK Tunas Mekar 33 responden. Hasil uji statistik dengan Independent t-test didapatkan $p$-value pada dua kelompok sebesar $0,868(\mathrm{p}>0,005)$ dengan kelompok intervensi kategori menyimpang mengalami penurunan sebesar 48,5\% dan kelompok kontrol mengalami penurunan $18,2 \%$.Hasil penelitian menunjukkan ada perbedaan sesudah pemberian stimulasi motorik halus terhadap tahap perkembangan anak usia prasekolah pada kelompok intervensi dan kontrol. Saran dalam penelitian ini sebaiknya orang tua memberikan stimulasi kepada anak usia prasekolah, sehingga dengan stimulasi yang diberikan anak akan mempunyai perkembangan psikososial yang normal.
\end{abstract}

Kata kunci: Anak Usia Prasekolah (3-6 tahun), Perkembangan Psikososial, Stimulasi Motorik Halus

\section{$A B S T R A C T$}

Preschool period is a golden period, where the development of a child will undergo many significant changes. Preschoolers have great potential for growth, the potential is developed by doing fine motor activities that are trained or used. The size of the moving instinct for the child is not always the same. In order for the growth of preschool children can be optimal then given the stimulation to provide stimulus to all aspects of child development. The stage of smooth motor development of the child will be achieved optimally provided the right stimulation. The Aim of the research is to know the influence of smooth motorik stimulation to the stage psychosocial development of preschool children age (3-6 years) in TK city district Kendal. This research design used quasy experiment with control group pre post test design. Sample of preschool children in kindergarten city districts Kendal is at kindergarten 
Muslimat there are 33 respondent and kindergarten Tunas Mekar there are 33 respondent. Statistical test results with Independent $t$-test obtained p-value in two groups of $0.868(p>0.005)$ with the category of deviant category intervention decreased by $48.5 \%$ and the control group decreased $18.2 \%$. The results showed there was a difference after provision of fine motor stimulation to the stage of development of preschool children in the intervention and control group. Suggestions in this study parents should provide stimulation to preschoolers, so with the stimulation provided the child will have normal psychosocial development.

Key words: Preschool Children age, Psychosocial Development, Smooth Motoric Stimulation

\section{PENDAHULUAN}

Anak usia prasekolah (3-6 tahun) memiliki potensi yang besar untuk segera berkembang, potensi tersebut akan berkembangapabila diberikan layanan berupa kesempatan melakukan kegiatan motorik yang dilatih atau digunakan sesuai dengan perkembangan anak tersebut. Besar kecilnya naluri bergerak bagi anaktidak selalu sama (Ujang, 2011).Anak usia prasekolah sebaiknya diberikan stimulasi supaya perkembangan motorik anak tidak terganggu (Sujiono, 2008).

Masa usia prasekolah merupakan masa emas, dimana perkembangan seorang anak akan banyak mengalami perubahan yang sangat berarti. Agar pertumbuhan anak usia prasekolah dapat optimal maka diberikan stimulasi untuk memberikan rangsangan terhadap seluruh aspek perkembangan anak (Soetjiningsih, 2010). Fase perkembangan psikososial pada anak usia prasekolah adalah inisiatif dan rasa bersalah. Perkembangan ini diperoleh dengan cara mengkaji lingkungan melalui kemampuan bereksplorasi terhadap lingkungannya. Anak belajar mengendalikan diri dan memanipulasi lingkungan. Anak mempunyai inisiatif berkembang dengan teman sekelilingnya. Kemampuan anak berbahasa meningkat, anak mulai menuntut untuk melakukan tugas dan bisa menghasilkan suatu prestasi (Soetjiningsih, 2010).

Perkembangan anak usia prasekolah dapat mengalami penyimpangan jika tidak diberikan stimulasi, salah satunya stimulasi yang diberikan yaitu motorik halus. Perkembangan psikososial anak usia prasekolah yaitu anak sudah bisa membantu pekerjaan yang sederhana, anak bisa bermain dengan alat dapur dan alat rumah tangga lainnya. Bermain dengan teman sebaya dengan permainan sesuai jenis kelamin, makan bersama keluarga dan bermain peran (Worshop keperawatan jiwa, 2015).

Penelitian di Amerika menunjukkan 9,5$14,5 \%$ anak mulai lahir sampai usia - tahun di Amerika mengalami masalah psikososial yang berdampak negatif terhadap mereka (Cooper, 2009 dalam penelitian Subandi 2012). Angka kejadian gangguan motorik halus pada anak prasekolah di Amerika Serikat berkisar 12-16\%, Thailand 24\%, Argentina 22\%, dan di Indonesia antara 13\%-18\%. Melihat angka epidemiologi tersebut, maka diperlukan adanya deteksi dinipada anak dengan gangguan perkembangan untuk mencegah terjadinya keterlambatan penanganan. Apabila tidak ditangani dengan tepat, maka gangguan ini dapat berlanjut hingga remaja atau dewasa (Susanto, 2011). Anak usia prasekolah mengalami gangguan perkembangan sebesar $62,02 \%$ (Widati, 2012). Dari data Riskesdas tahun (2013) angka prevelansi stunded (Hambatan pertumbuhan) pada anak usia prasekolah di Jawa Tengah adalah sebesar 24,5\% (Kemenkes, 2013). Data yang didapat dari Dinas Kesehatan Kabupaten Kendal pada tahun 2013 terdapat sebanyak1.136 anak prasekolah yang mengalami gangguan pertumbuhan dan perkembangan (DKK Kendal, 2013).

Aspek perkembangan anak usia dini meliputi motorik kasar, motorik halus, intelektual, moral, emosional, sosial, kognitif, dan bahasa (Suyanto, 2005). Kemampuan motorik halus (fine motor 
skills) pada anak meliputi kemampuankemampuan fisik anak yang melibatkan otot halus serta koordinasi mata dan tangan sehingga anak lebih bertanggung jawab terhadap dirinya serta perkembangan motorik halus terhadap perkembangan inteligensinya yang dapat menghasilkan gerakan motorik halus yang tepat, sehingga dibutuhkan koordinasi yang baik antara otak dengan otot-otot halus (Hasan, 2010).

Motorik halus merupakan aktivitas keterampilan yangmelibatkan gerakan otot-otot kecil seperti, menggambar, meronce manik, menulis, dan makan. Kemampuan motorik halus ini berkembang setelah kemampuan motorik kasar si kecil berkembang (Rudyanto, 2009). Motorik halus yaitu gerakan yang menggunakan otot halus yang dipengaruhi oleh kesempatan untuk belajar dan berlatih, misalnya memindahkan benda dari tangan, mencoret, menyusun, menggunting, dan menulis (Sujiono, 2008). Perkembangan kemampuan motorik halus diperlukan stimulasi yang diberikan kepada anak (Tanuwidjaya, 2010).

Tahap perkembangan motorik halus anak usia 3-6 tahun meliputi beberapa aspek motorik halus yang terdiri dari; membangun menara setinggi 11 kotak, menggambar sesuatu yang berarti bagi anak tersebut dan dapat dikenali oleh oranglain, mempergunakan gerakangerakan jemari selama permainan jari, menjiplak gambar kotak, menulis beberapa huruf. Anak usia 5 tahun mempunyai kemampuan pada aspek motorik halus yang terdiri dari; menulis nama depan, membangun menara setinggi 12 kotak, mewarnai dengan garis-garis, memegang pensil dengan benar antara ibu jari dan dua jari, menggambar orang beserta rambut hidung, menjiplak persegi panjang dan segitiga, memotong bentukbentuk sederhana (Silawati, 2008).

Tahap perkembangan motorik halus anak akan mampu dicapai secara optimal asal mendapatkan stimulasi tepat. Setiap fase, anak membutuhkan rangsangan untuk mengembangkan kemampuan mental dan motorik halusnya. Semakin banyak yang dilihat dan didengar anak, semakin banyak yang ingin diketahuinya sehingga kurang mendapatkan rangsangan anak akan bosan. Orang tua tidak boleh memberikan tekanan, persaingan, penghargaan, hukuman, atau rasa takut dapat mengganggu usaha yang dilakukan anak (Nuryani, 2009).

Perkembangan motorik yang terlambat berarti perkembangan motorik yang berada di bawah normal umur anak sehingga timbul dari kerusakan otak pada waktu lahir atau kondisi sebelum lahir, yang tidak menguntungkan atau lingkungan yang tidak menyenangkan setelah lahir namun keterlambatan lebih sering disebabkan oleh kurangnya kesempatan untuk mempelajari keterampilan motorik, perlindungan orang tua yang berlebihan, atau kurangnya motivasi anak untuk mempelajarinya (Hurlock, 2007).

Perkembangan anak membutuhkan stimulasi. Anak yang mendapat stimulasi yang terarah dan teratur lebih cepat berkembang dibandingkan dengan anak yang kurang/tidak mendapat stimulasi (Adriana, 2011). Anak akan mendapatkan stimulasi dengan baik pada pendidikan prasekolah atau Pendidikan Anak Usia Dini (PAUD). Hasil penelitian Rakhmanita (2010), menunjukkan bahwa ada perbedaan antara perkembangan motoric halus anak usia pra sekolah di kelompok bermain dengan tidak di kelompok bermain. Anak yang sejak usia dini mengikuti PAUD, mereka lebih mandiri, berkompeten, percaya diri, mengetahui dunia sosial, dan bisa menyesuaikan diri dengan keadaan sosial yang menyenangkan atauyang tidak menyenangkan (Santrock, 2005).

Penyimpangan perkembangan motorik halus tanpa mendapat penanganan dini dan memadai, kemungkinan besar berakhir dengankecacatan. Pemantauan perkembangan motorik halus anak dapat dilakukan dipusat pelayanan kesehatan posyandu, program Bina Keluarga Balita (BKB) dan lingkungan keluarga, sehingga peran keluarga terutama ibu sangatpenting, karena dengan pemantauan yang baik maka dapat dilakukan deteksidini pada kelainan perkembangan anak (Soetjiningsih, 2010).

Peran orang tua sangat bermanfaat bagi proses perkembangan anak secara keseluruhan karena orang tua dapat segera mengenali ke- 
lainan proses perkembangan anaknya sedini mungkin (Soetjiningsih, 2010). Penelitian yang dilakukan oleh Pradana (2007), menunjukkkan bahwa pola asuh orang tua diterapkan akan mempengaruhi tingkat perkembangan sosial anak usia 1-3 tahun.Penelitian Handayani (2012), menunjukkan alat permainan edukuatif dapat meningkatkan motorik halus anak, terbukti ada peningkatan motorik halus anak.

Pada perkembangan psikosoial ini anak mulai mencari pengalaman baru secara aktif. Apabila anak menapat dukungan dari orang tuanya untuk mengekplorasikan keingintahuannya maka anak akan mengambil inisiatif untuk suatu tindakan yang akan dilakukan, tetapi bila dilarang atau dicegah maka akan tumbuh perasaan bersalah pada diri anak (Wong, 2009).

Studi pendahuluan yang dilakukan di salah satu TK di Kecamatan Kendal didapatkan dari 10 anak yang ada di TK, semua anak mempunyai respon motorik halus yang kurang sebelum dilakukan stimulasi seperti belum bisa meniru gambar, menyusun balok dan setelah dilakukan stimulasi motorik halus anak-anak mempunyai respon yang bagus. Stimulasi yang diberikan seperti anak diajak bermain untuk membangun menara, menggerakkan jari-jarinya, meniru gambar kotak dan menulis nama depan. Sedangkan pada tahap perkembangan psikososial dari 10 anak, 6 anak malu, mudah menangis dan sulit untuk beradaptasi dengan teman maupun guru dan 4 anak prasekolah aktif dan berani bercerita tentang dirinya. Berdasarkan data di atas makapeneliti tertarik untuk meneliti judul pengaruh stimulasi motorik halus terhadap tahap perkembangan psikososial anak usia pra sekolah (3-6 tahun) di TK Kecamatan Kota Kendal.

\section{METODE}

Desain yang digunakan dalam penelitian ini adalah studi komparatif dua sampel dengan uji dua pihak. Rancangan penelitian yang digunakan adalah penelitian kuasi eksperimen dengan desain with control group pre post test design (Dharma, 2011). Populasi dalam penelitian ini adalah semua anak usia prasekolah yang ada di TK Kecamatan Kota Kendal. Sam- pel dalam penelitian ini adalah anak usia prasekolah di TK Kecamatan Kota Kendal yang terdiri dari TK Muslimat sebagai kelompok intervensi dan TK Tunas Mekar sebagai kelompok kontrol dengan jumlah responden masingmasing 33 yang memenuhi kriteria inklusi diantaranya Anak usia prasekolah dalam keadaan sehat dan bersedia menjadi responden. Teknik pengambilan sempel menggunakan Simple Random Sampling sampel acak sederhana (Setiawan, 2010). Data diambil menggunakan kuesioner terkait karakteristik (usia, jenis kelamin, pendidikan orang tua, pekerjaan orang tua dan jumlah saudara kandung), stimulasi motorik halus anak prasekolah usia 3-6 tahun, dan tahap perkembangan psikososial anak usia prasekolah (3-6 tahun).

Kuesioner terlebih dahulu dilakukan uji validitas dan uji reliabilitas. Hasil uji validitas kuesioner mempunyai nilai rentang 0,931-0,661 (ciri anak usia prasekolah yang inisiatif), 0,9510,858 (keterampilan atau gerakan), 0,951-0,715 (keterampilan atau gerakan halus), 0,957-0,866 (perkembangan aspek kognitif), 0,964-0,762 (perkembangan aspek bahasa), 0,907-0,769 (perkembangan aspek emosi), 0,907-0,769 (perkembangan aspek kepribadian), 0,978-0,881 (perkembangan aspek moral), 0,978-0,881 (perkembangan aspek spiritual), dan 0,931-0,714 (perkembangan aspek psikososial), sehingga semua kuesioner dinyatakan valid karena mempunyai nilai $>0,361$.

Uji reliabilitas kuesioner mempunyai nilai Alpha Cronbach 0,975 (ciri anak usia prasekolah yang inisiatif), 0,899 (keterampilan atau gerakan), 0,906 (keterampilan atau gerakan halus), 0,942 (perkembangan aspek kognitif), 0,904 (perkembangan aspek bahasa), 0,912 (perkembangan aspek emosi), 0,792 (perkembangan aspek kepribadian), 0,792 (perkembangan aspek moral), 0,942 (perkembangan aspek spiritual), dan 0,918 (perkembangan aspek psikososial(, sehingga semua kuesioner dinyatakan reliabel karena nilai Alpha Cronbach > 0,60.

Analisis univariat dalam penelitian ini menggunakan distribusi frekuensi dan karak- 
teristik usia, agama, jenis kelamin, jumlah saudara pendidikan orang tua, pekerjaan orang tua. Analisa bivariat pada stimulasi perkembangan psikososial usia prasekolah sebelum dan sesudah intervensi pada kelompok intervensi atau kelompok kontrol dianalisis menggunakan Paired t-test. Sedangkan stimulasi perkembangan psikososial usia prasekolah sesudah intervensi pada kelompok intervensi dibanding kelompok kontrol dianalisis menggunakan Independent-test.
Penelitian menggunakan Informed consent untuk meminta persetujuan kepada responden, jika ada responden yang tidak bersedia maka tidak dijadikan sampel dalam penelitian. Peneliti tidak mencantumkan nama responden (Anonimity) dan hanya diberi kode saja karena untuk menjaga rahasia, menghormati privasi dan kerahasiaan subyek penelitian (respect for privacy and confidentiality). Kerahasiaan (Confidentiality) informasi responden dijamin

Tabel 1. Karakteristik Responden berdasarkan Usia $(n=33)$

\begin{tabular}{lcccc}
\hline \multicolumn{1}{c}{ Variabel } & Median & Min-Max & SD & CI 95\% \\
\hline Usia intervensi & 5,00 & $4-6$ & 0,684 & $5,06-5,55$ \\
Usia kontrol & 6,00 & $4-6$ & 0,614 & $5,36-5,79$ \\
\hline
\end{tabular}

Tabel 2. Karakteristik Responden Berdasarkan, Jenis Kelamin, Pendidikan Orang Tua, Pekerjaan (n=33)

\begin{tabular}{|c|c|c|c|c|c|}
\hline \multirow[t]{2}{*}{ No } & \multirow[t]{2}{*}{ Variabel } & \multicolumn{2}{|c|}{ Kelompok intervensi } & \multicolumn{2}{|c|}{ Kelompok kontrol } \\
\hline & & f & $\%$ & f & $\%$ \\
\hline \multirow[t]{4}{*}{1} & Jenis kelamin & & & & \\
\hline & Laki-laki & 13 & 39,4 & 14 & 42,4 \\
\hline & Perempuan & 20 & 60,6 & 19 & 57,6 \\
\hline & Total & 33 & 100,0 & 33 & 100,0 \\
\hline \multirow[t]{5}{*}{2} & Jumlah saudara & & & & \\
\hline & 1 & 10 & 30,0 & 21 & 63,6 \\
\hline & 2 & 2 & 6,1 & 2 & 6,1 \\
\hline & 3 & 21 & 63,6 & 10 & 30,0 \\
\hline & Total & 33 & 100,0 & 33 & 100,0 \\
\hline \multirow[t]{7}{*}{3} & Pendidikan orang tua & & & & \\
\hline & SD & 3 & 9,1 & 4 & 12,1 \\
\hline & SMP/MTS & 4 & 12,1 & 3 & 9,1 \\
\hline & SMA/MA & 16 & 48,5 & 13 & 39,4 \\
\hline & D3 & 5 & 15,2 & 9 & 27,3 \\
\hline & $\mathrm{S} 1$ & 5 & 15,2 & 4 & 12,1 \\
\hline & Total & 33 & 100,0 & 33 & 100,0 \\
\hline \multirow[t]{9}{*}{4} & Pekerjaan orang tua & & & & \\
\hline & Petani & 9 & 27,3 & 15 & 45,5 \\
\hline & Pedagang & 5 & 15,2 & 4 & 12,1 \\
\hline & Ibu rumah tangga & 2 & 6,1 & 2 & 6,1 \\
\hline & PNS & 4 & 12,1 & 1 & 3,0 \\
\hline & Guru & - & - & 4 & 12,1 \\
\hline & Perawat & 3 & 9,1 & 2 & 6,1 \\
\hline & Karyawan & 10 & 30,0 & 5 & 15,2 \\
\hline & Total & 33 & 100,0 & 33 & 100,0 \\
\hline
\end{tabular}


oleh peneliti, hanya kelompok data tertentu yang dilaporkan sebagai hasil penelitian. Keadilan dan inklusivitas (respect for justice and inclusiveness) serta memperhitungkan manfaat dan kerugian yang ditimbulkan (balancing harms and benefits) (Notoatmodjo, 2010). Peneliti melakukan penelitian di TK Muslimat sebagai kelompok intervensi, dimana di TK tersebut diberikan pre-test selanjutnya pemberian stimulasi motorik halus dan dilakukan post test. Sedangkan di TK Tunas Mekar merupakan kelompok kontrol yaitu dilakukan pre test kemudian minggu kedua dilakukan post test dan selanjutnya diberikan stimulasi motorik halus.

\section{HASIL}

\section{Karakteristik Responden}

Adapun karakteristik Responden dapat dilihat pada table 1. Hasil penelitian menunjukkan pada kelompok intervensi, mayoritas responden beragama Islam, berjenis kelamin perempuan, mempunyai jumlah saudara sebanyak 3 orang, orang tua berpendidikan SMA/MA dan bekerja sebagai karyawan sedangkan pada kelompok kontrol menunjukkan mayoritas responden beragama islam, berjenis kelamin perempuan, mempunyai saudara 1 , orang tua berpendidikan SMA/MA dan bekerja sebagai petani.

\section{Pengaruh Tahap Perkembangan Terhadap Stimulasi Pada Kelompok Intervensi dan Kontrol}

Hasil analisis didapatkan nilai median pada kelompok intervensi sebelum stimulasi didapatkan nilai median 38, sehingga peneliti mengkategorikan hasil menyimpang jika nilai hasil kuesioner 38, dan dikatagorikan normal jika hasil kuesioner $>38$. Sedangkan sesudah stimulasi nilai median 42, maka peneliti mengkategorikan hasil menyimpang jika nilai hasil kuesioner 42 dan dikategorikan normal jika hasil kuesioner $>42$. Pada kelompok intervensi sebelum dan sesudah intervensi berupa pendidikan

Tabel 3. Pengaruh Tahap Perkembangan Terhadap Stimulasi Pada Kelompok Intervensi dan Kontrol $2016(n=33)$

\begin{tabular}{lccccc}
\hline Variabel tahap perkembangan psikososial & \multicolumn{2}{c}{ Pre } & \multicolumn{2}{c}{ Post } & P value \\
\cline { 2 - 6 } & f & $\mathbf{\%}$ & $\mathbf{f}$ & $\mathbf{\%}$ & \\
\hline Intervensi & 10 & 30,3 & 26 & 78,8 & 0,000 \\
Normal & 23 & 69,7 & 7 & 21,2 & \\
Menyimpang & 33 & 100,0 & 33 & 100,0 & \\
Total & & & & & \\
Kontrol & 26 & 78,8 & 28 & 48,5 & 0,012 \\
Normal & 7 & 21,2 & 5 & 51,5 & \\
Tenyimpang & 33 & 100,0 & 33 & 100,0 & \\
\hline
\end{tabular}

Tabel 4. Pengaruh Tahap Perkembangan Pada Kelompok Intervensi dan Kontrol Sesudah Intervensi (n=33)

\begin{tabular}{|c|c|c|c|c|c|}
\hline \multirow{2}{*}{$\begin{array}{l}\text { Analisis bivariat } \\
\text { sesudah intervensi }\end{array}$} & \multicolumn{2}{|c|}{ Kelompok intervensi } & \multicolumn{2}{|c|}{ Kelompok kontrol } & \multirow[t]{2}{*}{ P value } \\
\hline & $\mathbf{F}$ & $\%$ & f & $\%$ & \\
\hline Normal & 26 & 78,8 & 28 & 48,5 & \\
\hline Menyimpang & 7 & 21,2 & 5 & 51,5 & 0,868 \\
\hline Total & 33 & 100,0 & 33 & 100,0 & \\
\hline
\end{tabular}


kesehatan nilai median 38 .

Hasil analisis menunjukkan bahwa kelompok kontrol dan intervensi dengan uji (Skewness) didapatkan hasil sebelum intervensi 0,954, sesudah intervensi $-1,515$, sebelum kontrol 0,769 , sesudah kontrol -0,012 disebut nilai $\mathrm{z}(\mathrm{z}<1,96)$ ini diartikan bahwa semua data berdistribusi normal. Sehingga untuk menganalisis pengaruh stimulasi motorik hasul terhadap perkembangan psikososial anak pra sekolah sebelum dan sesudah pemberian stimulasi pada masing-masing kelompok peneliti menggunakan ujia Paired t-test, sedangkan untuk menganalisis perbedaan tingkat terhadap tahap perkembangan pada kedua kelompok setelah pemberian intervensi peneliti menggunakan uji Independent t-test. Adapun Pengaruh Tahap Perkembangan Terhadap Stimulasi Pada Kelompok Intervensi dan Kontrol dapat dilihat pada tabel 3 .

Berdasarkan tabel 3 hasil analisis pada kelompok intervensi menunjukkan hasil sebelum stimulasi didapatkan tahap perkembangan mayoritas menyimpang $23(69,7 \%)$, sesudah stimulasi mayoritas normal $26(78,8 \%)$. Hasil analisis uji paired t-tes didapatkan nilai $\mathrm{P}=0,000$ $(\mathrm{P}<0,05)$ diartikan bahwa ada pengaruh sebelum dan sesudah pemberian stimulasi. Hasil analisis pada kelompok kontrol menunjukkan hasil sebelum stimulasi didapatkan tahap perkembangan mayoritas normal $26(78,8 \%)$, sesudah stimulasi mayoritas normal $28(48,5 \%)$. Hasil analisis uji paired t-tes didapatkan nilai $\mathrm{P}=0,012(\mathrm{P}>0,05)$ diartikan bahwa tidak ada pengaruh sebelum dan sesudah pemberian stimulasi.

Berdasarkan tabel 4 Hasil analisis menunjukkan t hitung 0,868 ini dapat diartikan bahwa Ho ditolak sehingga ada perbedaan antara kelompok intervensi dan kelompok kontrol sesudah pemberian stimulasi.

\section{PEMBAHASAN}

\section{Karakteristik responden}

Hasil penelitian menunjukkan rentang usia responden pada kelompok intervensi dan kelompok kontrol 4-6 tahun. Hasil tersebut didukung oleh penelitian Supriyanto (2010) tentang pengaruh stimulasi motorik kasar terhadap perkembangan motorik kasar anak usia prasekolah di TK Nurul Falah Desa Ringinarum didapatkan hasil anak usia prasekolah yaitu 5 dan 6 tahun sebanyak 78 (86,5\%). Hasil penelitian menunjukkan tahap perkembangan anak usia 4 sampai 6 tahun di TK Kecamatan Kota Kendal anak bisa bermain dengan temannya, mampu bersosialisasi dan mampu makan bersama temannya. Hasil tersebut sesuai pendapat Soetjiningsih (2010) anak usia prasekolah anak sudah mampu sosialisasi dengan teman, sudah bisa dilakukan stimulasi dan perkembangan sosial anak usia 5 tahun ditandai dengan sudah bisa bersahabat, menunjukkan partisipasinya dalam kelompok, kebutuhan akan kepastian dan kenyamanan dari orang tua, suka menghibur orang lain, dan ingin menorehkan prestasi. Menurut Wong (2009) kemampuan motorik halus anak usia prasekolah meliputi menggunting sesuai pola, menyusun mainan konstruksi bangunan, mewarnai lebih rapi tidak keluar garis dan meniru tulisan.

Hasil penelitian anak usia 4-6 tahun di TK Kec. Kota Kendal mampu melakukan berdoa sebelum makan, memiliki keberanian tampil didepan, hasil tersebut sesuai pendapat Hurlock (2009) tugas-tugas perkembangan anak usia 4-5 tahun diantaranya yaitu mempelajari keterampilan fisik yang diperlukan untuk permainan yang umum dan mengembangkan keterampilanketerampilan dasar untuk membaca, menulis dan berhitung. Munkhur (2010) mengatakan perkembangan anak pada usia 4-6 tahun sangat peka terhadap stimulus dan pengalaman serta mempunyai kemampuan plastisitas yang tinggi, anak usia 3-6 tahun jika diberikan stimulasi motorik halus mampu menulis, menggambar, menyusun balok dan memasukkan kelereng sesuai dengan tahap perkembangannya.

Hasil penelitian ini didukung oleh Maryanah (2010) pengaruh karakteristik anak usia prasekolah sebelum dan sesudah dilakukan stimulasi motorik halus di TK Pertiwi Gunung Pati didapatkan hasil sebagian anak usia prasekolah berusia 4-6 tahun hal ini dikarenakan anak usia 4 -6 tahun merupakan anak usia prasekolah. 
Berdasarkan hasil penelitian dan pendapat beberapa literatur, peneliti menyimpulkan bahwa karakteristik anak usia 5 dan 6 tahun karena usia ini stimulasi yang optimal akan mengoptimalisasi pertumbuhan otak anak usia prasekolah dalam hal perkembangan psikososial. Anak usia prasekolah usia 3-6 tahun setelah diberikan stimulasi motorik halus akan mampu beraktivitas dengan menggunakan otot halus (kecil) seperti menulis, menggambar, menyusun balok dan memasukkan kelereng kedalam botol dan anak usia prasekolah sudah bisa menggunting sesuai pola, menyusun mainan konstruksi bangunan, mewarnai lebih rapi tidak keluar garis dan meniru tulisan.

Hasil penelitian menunjukkan bahwa sebagian besar responden di TK Kec. Kota Kendal berjenis kelamin perempuan $(60,0 \%)$ pada kelompok intervensi dan $(57,6 \%)$ pada kelompok kontrol. Hasil tersebut sesuai pendapat Wahyuni (2012) yang menjelaskan bahwa jenis kelamin anak menentukan perkembangan motorik halus anak usia prasekolah. Hasil penelitian tersebut sesuai dengan penelitian yang dilakukan oleh Anik (2009) yang berjudul perbedaan kematangan sosial anak ditinjau dari keikutsertakan pendidikan prasekolah (play group) yang berusia 35 tahun yang tinggal di daerah Pasar Kliwon Surakarta didapatkan hasil sebagai besar responden berjenis kelamin perempuan sebanyak 78,6\% sedangkan anak perempuan akan mudah diberikan stimulasi dibandingkan anak laki-laki karena anak perempuan lebih mudah diatur dari pada anak laki-laki.

Hasil penelitian menunjukkan bahwa sebagian besar responden di TK Kec. Kota Kendal kelompok intervensi mempunyai jumlah saudara $3(63,6 \%)$ pada kelompok kontrol mempunyai saudara $1(63,6 \%)$. Hasil penelitian ini sejalan dengan penelitian yang dilakukan Mutmainah (2013) tentang pola asuh orang tua dengan perkembangan anak usia prasekolah di TK Raudatul Athfal Sukorejo didapatkan sebagian besar mempunyai saudara kandung 2 sebanyak
$64,8 \%$ dan orang tua mempunyai pola asuh yang baik sehingga perkembangan anak normal.

Hasil penelitian menunjukkan bahwa pendidikan orang tua SMA/MA $(48,5 \%)$ pada kelompok intervensi dan $(39,4 \%)$ pada kelompok kontrol. Hal ini sesuai pendapat Novera (2010) yaitu semakin tinggi pendidikan seseorang maka semakin baik tingkat pengetahuannya hal ini dikarenakan pendidikan orang tua berhubungan dengan pemberian stimulasi kepada anak sedangkan menurut Walker (2007) semakin tinggi tingkat pendidikan ayah dan ibu, semakin besar stimulasi motorik halus yang diberikan kepada anak.

Hasil ini sesuai pendapat Hariweni (2013) tingkat pendidikan orang tua berpengaruh terhadap peningkatan kualitas sumber daya manusia. Dengan tingkat pendidikan yang tinggi maka seseorang akan dapat lebih mudah mengikuti perkembangan ilmu dan kemajuan teknologi sehingga akan mudah memberikan stimulasi kepada anaknya. Menurut Notoatmodjo (2010) orang tua mempunyai peranan yang penting terutama dalam proses pertumbuhan dan perkembangan serta pembentukan pribadi seseorang. Orang tua merupakan pendidik pertama bagi anak-anaknya. Penelitian yang sama dilakukan oleh Krisnawati (2010) tentang pengaruh pendidikan orang tua terhadap perkembangan anak usia prasekolah di Desa Pamriyan Gemuh didapatkan hasil pendidikan orang tua SMA $(76,5 \%)$. Hal tersebut sesuai dengan teori Notoatmodjo (2012) pendidikan orang tua akan mempengaruhi tahap perkembangan anak.

Hasil penelitian menunjukkan bahwa sebagian besar responden di TK Kec. Kota Kendal bekerja sebagai karyawan $(30,0 \%)$ pada kelompok intervensi dan (45,5\%) bekerja sebagai petani pada kelompok kontrol. Hasil penelitian yang sama dilakukan oleh Pradana (2007), yang meneliti tentang hubungan antara pola asuh orang tua terhadap tingkat perkembangan sosial anak usia 1-3 tahun di desa Malangjiwan wilayah kerja Puskesmas Colomadu 1 Kabupaten Karanganyar didapatkan hasil pekerjaan orang tua petani. 
Mengidentifikasi tahap perkembangan psikososial anak usia pra sekolah (3-6 tahun) sebelum dan sesudah di lakukan stimulasi pada kelompok intervensi di TK Muslimat

Hasil penelitian menunjukkan bahwa sebagian besar responden sebelum diberikan stimulasi tahap perkembangan psikososial menyimpang sebanyak $(69,7 \%)$ dan tahap perkembangan psikososial setelah diberikan stimulasi normal sebanyak $(78,8 \%)$. Hasil penelitian menunjukkan bahwa anak yang kurang mendapatkan stimulasi akan mengalami hambatan dalam pertumbuhan dan perkembangannya serta kesulitan dalam berinteraksi dengan orang lain. Hasil tersebut sesuai pendapat Hurlock (2009) yaitu stimulasi yang diberikan pada anak selama tiga tahun pertama (golden age) akan memberikan pengaruh yang sangat besar bagi perkembangan otaknya dan menjadi dasar pembentuk kehidupan yang akan datang. Semakin dini stimulasi yang diberikan maka perkembangan anak akan semakin baik. Semakin banyak stimulasi yang diberikan maka pengetahuan anak akan menjadi luas sehingga perkembangan anak semakin optimal. Hasil penelitian didapatkan stimulasi akan mempengaruhi perkembangan anak, semakin baik stimulasi motorik halus yang diberikan maka perkembangan psikososial anak juga akan normal.

Hasil tersebut sesuai dengan pendapat Gunarsa (2010) menyatakan bahwa kemampuan motorik anak berkaitan erat dengan self-image anak atau rasa percaya diri. Anak yang memiliki kemampuan motorik yang lebih baik di bidang olah raga akan menyebabkan anak dihargai teman-temannya. Peranan kemampuan motorik pada anak juga berpengaruh terhadap dorongan anak dapat menghibur dirinya dan memperoleh perasaan senang. Seperti anak merasa senang dengan memiliki keterampilan memainkan komputer, bermain bola bola atau memainkan alat elektorik atau mainan lainnya.

Tahap perkembangan psikososial anak prasekolah termasuk dalam tahap perkembangan inisiatif versus rasa bersalah. Pada tahap ini anak mulai mencari pengalaman baru secara aktif. Apabila anak mendapat dukungan dari orang tuanya untuk mengekplorasikan keingintahuannya nya maka anak akan mengambil inisiatif untuk suatu tindakan yang akan dilakukan, tetapi bila dilarang atau dicegah maka akan tumbuh perasaan bersalah pada diri anak (Wong, 2009). Ciri anak usia prasekolah yang inisiatif meliputi memiliki inisiatif/ gagasan atau ide, tidak malas beraktivitas fisik, beranmengungkapkan pendapat, mampu berfantasi, mampu mengatasi masalah, tidak mudah menyerah, tidak mudah putus asa, tidak suka menyendiri/mudah sosialisasi, banyak bertanya, percaya diri dan tidak takut salah melakukan sesuatu. Peneliti berasumsi bahwa sebelum diberikan stimulasi perkembangan anak menyimpang dan setelah diberikan stimulasi perkembangan anak normal yaitu mengalami peningkatan hal ini dikarenakan stimulasi mempengaruhi perkembangan psikososial anak sehingga anak akan berani mengungkapkan pendapat dan ide maupun gagasan, berani tampil dan tidak mudah menyerah.

\section{Mengidentifikasi tahap perkembangan psikososial anak usia pra sekolah (3-6 tahun) sebelum dan setelah dilakukan stimulasi pada kelompok kontrol di TK Tunas Mekar}

Hasil penelitian menunjukkan bahwa sebagian besar responden sebelum diberikan stimulasi tahap perkembangan psikososial normal sebanyak (78,8\%) dan tahap perkembangan psikososial setelah diberikan stimulasi normal sebanyak (48,5\%). Penelitian ini didukung oleh Hurlock (2009) yang mengatakan perkembangan motorik merupakan perkembangan pengendalian gerakan jasmaniah melalui kegiatan pusat syaraf, urat syaraf, dan otot yang terorganisasi. Hal ini dikarenakan anak belum bisa melakukan motorik halus karena belum adanya stimulasi dari guru dan orang tua. Perkembangan motorik halus anak usia 3-6 tahun berbeda-beda untuk setiap anak, sehingga anak yang belum diberikan stimulasi mempunyai perkembangan psikososial menyimpang.

Hasil tersebut sesuai dengan pendapat Wong (2009) yang menyatakan bahwa perkembangan psikososial menyimpang sebelum dilakukan stimulasi dikarenakan anak usia 3-6 tahun belum 
pernah mendapatkan stimulasi seperti menggunting mengikuti bentuk gambar, menggambar bulatan, kotak, bulan, bintang, rumah dan orang, memasukkan biji kacang ijo ke dalam botol dan menggambar atau melukis dengan pensil warna sehingga mereka belum bisa melakukan. Hasil tersebut sesuai dengan pendapat Safaria (2010) yang menyatakan tindakan pemberian stimulasi dilakukan dengan prinsip bahwa stimulasi hendaknya dilakukan dengan wajar, tanpa paksaan atau marah bila anak tidak dapat melakukannya, memberi pujian bila anak berhasil. Kurangnya stimulasi akan mempengaruhi perkembangan motorik halus dan dampak yang timbul bila anak mengalami gangguan dalam perkembangan.

Keterampilan yang sudah dicapai berdasarkan aspek perkembangan keterampilan atau gerakan anak prasekolah yaitu keterampilan atau gerakan kasar yang meliputi berjalan diatas papan titian, bermain lompat tali, bermain lompat karung dan keterampilan atau gerakan halus meliputi menggunting mengikuti bentuk gambar, menggambar bulatan, kotak, bulan, bintang, rumah dan orang, memasukkan barang ke dalam botol dan menggambar atau melukis dengan pensil warna (Workshop keperawatan jiwa, 2015).

Anak prasekolah yaitu perkembangan aspek emosi yang meliputi mengenal dan mengekspresikan perasaan yang sedang dialami, menunda dan tidak memaksakan keinginan, mampu mengucapkan terima kasih atas pemberian orang tua, meminta maaf jika melakukan kesalahan. Perkembangan aspek kepribadian yang meliputi menyebutkan nama lengkap, nama panggilan dan jenis kelamin, mengenal, menerima dan membandingkan bentuk/ukuran tubuh dan memiliki keberanian tampil di depan umum (Workshop keperawatan jiwa, 2015)

Hasil penelitian ini juga sesuai dilakukan oleh Barros (2010) bahwa anak-anak yang mendapatkan stimulasi nilainya lebih tinggi dan anak yang pendidikan ibunya lebih rendah, kemampuan perkembangannya lebih baik. Hal ini menunjukkan keberhasilan suatu stimulasi tidak tergantung dari pendidikan orangtua tetapi lebih ditentukan oleh efektifitas dan kesinambungan stimulasi pada anak. Penelitian ini sejalan dengan penelitian yang dilakukan oleh Winarsih (2014) tentang pengaruh pengetahuan ibu tentang stimulasi dengan perkembangan motorik halus anak usia 3-6 tahun di TK PAUD Pepaya dan Sakura di desa Bakulan Kulon Kabupaten Bantul didapatkan hasil ada pengaruh pengetahuan ibu tentang stimulasi dengan perkembangan motorik halus anak usia 3 -6 tahun.

Peneliti berasumsi sebelum diberikan stimulasi perkembangan anak normal dan setelah diberikan stimulasi juga mengalami peningkatan hal ini dikarenakan selain disekolah anak juga mendapatkan stimulasi yang berasal dari orang tua dan keluarganya seperti saudaranya, anak sudah bisa menggunting mengikuti bentuk gambar, menggambar bulatan, kotak, bulan, bintang, rumah dan orang, memasukkan barang ke dalam botol dan menggambar atau melukis dengan pensil warna.

Pengaruh tahap perkembangan psikososial sesudah dilakukan stimulasi motorik halus anak usia pra sekolah (3-6 tahun) pada kelompok intervensi dibanding kelompok kontrol

Hasil penelitian menunjukkan ada pengaruh tahap perkembangan psikososial sesudah diberikan stimulasi yaitu $p$ value 0,0868 hal ini dikarenakan adanya stimulasi dari orang tua, stimulus merupakan kebutuhan yang sangat penting dalam tumbuh kembang anak. Anak yang banyak mendapat stimulus yang terarah akan cepat berkembang dibandingkan dengan anak yang kurang atau bahkan tidak mendapat stimulus. Stimulasi adalah perangsangan yang datang dari lingkungan luar anak antara ain berupa latihan dan bermain. Stimulasi merupakan cikal bakal proses pembelajaran dan sangat penting dalam tumbuh kembang anak (Hurlock, 2009). Stimulasi juga dapat berfungsi sebagai penguat yang bermanfaat bagi perkembangaan anak. Stimulasi harus dilaksanakan dengan penuh perhatiaan dan kasih sayang (Narendra, 2008).

Perkembangan aspek psikososial anak usia 
prasekolah meliputi membantu pekerjaan sederhana, bermain dengan alat dapur dan alat rumah tangga, bermain dengan teman sebaya dengan permainan sesuai jenis kelamin, makan bersama keluarga, bermain peran (misalnya jual beli) dan tahap perkembangan spiritual meliputi berdoa sebelum dan sesudah kegiatan, beribadah bersama keluarga dan mendengarkan dan membaca kitab suci. Hasil penelitian Suryawan (2010) menyatakan beberapa faktor yang mempengaruhi keberhasilan stimulasi antara lain kemampuan dasar individu, kesehatan, keluarga, lingkungan, serta keadaan sosial ekonomi. Selain itu juga dipengaruhi oleh kapan waktu awal diberikan stiulasi, berapa lama, dan bagaimana cara melakukannya. Kemampuan perkembangan anak mempunyai ciri yang khas, yaitu mempunyai pola yang tetap dan terjadi secara berurutan, sehingga stimulasi dini yang dilakukan harus terarah dan ditekankan terlebih dahulu untuk pembentukan kemampuan dasar sebelum mengembangkan kemampuan kognitifakademik dan perilaku yang lebih kompleks.

Hasil penelitian ini juga sesuai dengan pendapat Vivian (2010) menyatakan bahwa stimulasi ini dapat merangsang hubungan antar sel otak (sinaps), milyaran sel otak dibentuk sejak kehamilan berusia 6 bulan. Pada saat itu belum ada hubungan antar sel otak, bila ada rangsangaan maka akan terbentuk hubungan. Jika rangsangan sering diberikan, maka hubungan akan semakin kuat. Jika variasi rangsangan banyak maka akan terbentuk hubungan yang semakin kompleks atau luas, dengan demikian dapat merangsang otak kiri dan kanan sehingga dapat terbentuklah multipel intelegen dan kecerdasan yang lebih luas dan tinggi.

Stimulasi dan intervensi sejak dini untuk meningkatkan kemampuan kecerdasan motorik harus dilakukan sejak dini sesuai dengan kelebihan dan kekurangannya. Orangtua harus dapat memahami dan mendeteksi kelebihan dan kekurangan kecerdasan motorik anak sehingga dapat meningkatkan prestasi pada kelebihannya tetapi sebaliknya dapat melatih kekurangannya agar tidak lebih tertinggal. Kelebihan motorik halus dan motorik kasar seorang anak bila terdeteksi sejak dini dan dilakukan stimulasi dan latihan lebih rutin sejak kecil akan menghasilkan prestasi besar sesuai dengan kelebihan tingkat motoriknya.

Tindakan memberikan stimulasi pada anak adalah untuk membantu anak mencapai tingkat perkembangan optimal atau sesuai dengan apa yang diharapkan. Stimulasi dilakukan oleh orang tua atau keluarga setiap ada kesempatan atau sehari-hari. Stimulasi disesuaikan dengan usia anak tersebut dengan tidak mengabaikan prinsipprinsip stimulasi (Hurlock, 2009). Berdasarkan hasil penelitian dan pendapat beberapa literatur, peneliti menyimpulkan ada pengaruh stimulasi motorik halus terhadap tahap perkembangan psikososial anak usia prasekolah hal ini dikarenakan adanya peningkatan sebelum dan sesudah diberikan stimulasi. Peneliti berpendapat perkembangan anak usia prasekolah sebelum dan setelah diberikan stimulasi perkembangan psikososial ada perubahan yaitu sebelum diberikan stimulasi perkembangan psikososial menyimpang dan setelah diberikan stimulasi perkembangan normal hal ini dikarenakan stimulasi memberikan pengaruh kepada anak usia prasekolah, karena stimulasi merupakan perangsangan yang datangnya dari lingkungan luar individu anak. Anak yang mendapatkan stimulasi akan lebih cepat berkembang dari pada anak yang kurang atau bahkan tidak mendapat stimulasi. Pemberian stimulasi akan lebih efektif apabila memperhatikan kebutuhan-kebutuhan anak sesuai tahap-tahap perkembangan yang meliputi perkembangan aspek kognitif, perkembangan aspek bahasa, perkembangan aspek emosi dan kepribadian, perkembangan aspek moral dan spiritual dan perkembangan aspek psikososial.

\section{SIMPULAN DAN SARAN Simpulan}

Ada pengaruh tahap perkembangan psikososial sebelum dan sesudah diberikan stimulasi pada kelompok intervensi di banding kelompok kontrol ( $p$ value 0,868 ).

\section{Saran}

Sebaiknya orang tua memberikan stimulasi 
secara teratur kepada anaknya. Diharapkan orang tua mengerti akan arti pentingnya stimulasi motorik halus pada usia anak prasekolah.

\section{DAFTAR PUSTAKA}

Barros. (2010). Antraoperative intravenous lidocain.Revista Brasileira de Anestesiologia.

Dharma, Kusuma Kelana (2011), Metodologi Penelitian Keperawatan : Panduan. Melaksanakan dan Menerapkan Hasil Penelitian, Jakarta, Trans InfoMedia.

Gunarsa. (2010). Psikologi Untuk Membimbing, Jakarta: Balai Pustaka

Hariweni. (2013). Komunikasi Dalam Keperawatan. Jakarta

Hasan. (2010). PAUD (Pendidikan Anak Usia Dini). Jogjakarta:Diva Press.

Hurlock. (2009). Perkembangan Anak, Jakarta: Erlangga.

IDAI. (2012). Respirologi Anak, IDAI, Jakarta

Krisnawati. (2010) Pengaruh pendidikan orang tua terhadap perkembangan anak usia prasekolah di Desa Pamriyan Gemuh

Maryanah. (2010) Karakteristik anak usia prasekolah sebelum dan sesudah dilakukan stimulasi motorik halus di TK Pertiwi Gunung Pati

Munkhur (2010). Perkembangan anak pada usia 4-6 tahun sangat peka terhadap stimulus dan pengalaman serta mempunyai kemampuan plastisitas yang tinggi.

Narendra. (2008). Buku Ajar I Tumbuh Kembang Anak dan Remaja Edisi Pertama IDAI. Jakarta : Sagung Set

Notoatmodjo, S. (2010). Metodologi penelitian kesehatan. Jakarta : rineka cipta.

Notoatmodjo, S. (2012). Pengantar Pendidikan Kesehatan dan Ilmu Perilaku Kesehatan. BPKM FKM-UI

Novera (2010). Pengaruh persepsi Siswa SMK Tentang Dunia Kerja Terhadap Motivasi Untuk Melanjutkan ke Perguruan Tinggi. Skripsi SI Jurusan PTS FPTK UPI Bandung : tidak diterbitkan.

Rudyanto. (2009). Pembelajaran Kooperatif untuk Meningkatkan Keterampilan Anak. Jakarta: Depdiknas.
Safaria. (2015). Evaluasi Pembelajaran, Jakarta, Departemen Pendidikan

Soetjiningsih. (2007). Buku Ajar Tumbuh Kembang Remaja dan Permasalahannya. Jakarta : Sagung Seto

Sujiono. (2008). Psikologi Perkembangan Anak. Jakarta. Univesitas Terbuka

Suryawan (2010). Meningkatkan Pemahaman Anak Terhadap. Pendidikan Moral Melalui Peningkatan Kemampuan Kognitif

Susanto. (2011). Perkembangan Anak Usia Dini. Jakarta. Sagung Seto

Suyanto. (2005). Dasar-dasar Pendidikan Anak Usia Dini, (Yogyakarta: Hikayat Publishing).

Tanuwidjaya. (2010). Konsep Umum Tumbuh dan Kembang, Jakarta: EGC

Ujang. (2011). Konsep Dasar Perkembangan Potensi Motorik Anak Usia Prasekolah. Tahun VII, No 12. http://digilib.unipasby.ac.id (diakses tanggal 9 Oktober 2015).

Vivian (2010). Psikologi Perkembangan, Universitas Gajah Mada, Yogyakarta

Walker (2007). Detecting and predicting financial statement fraud: The effektivennes of fraud triangle and sas No. 99

Winarsih (2014). Manajemen Pelayanan, Jakarta: Pustaka.

Wong. (2009). Buku Ajar Keperawatan Pediatrik. Vol. 1. Edisi 6. Jakarta : EGC

Worshop keperawatan jiwa. (2015). Standar asuhan keperawatan jiwa. Gangguan resiko dan sehat. Universitas Indonesia. 